\title{
THE DISTRIBUTION OF TOTAL BODY CHLORIDE IN MAN 1
}

\author{
BY NORMAN DEANE, MORRIS ZIFF, AND HOMER W. SMITH \\ (From the Departments of Physiology and Medicine, New York University College of Medicine, \\ New York City)
}

(Submitted for publication June 22, 1951 ; accepted November 12, 1951)

The studies of Weir (1), Weir and Hastings (2), and Wallace and Brodie (3) have demonstrated the similarity of bromide and chloride distribution in tissues and body fluids of dogs and cats. With the exception of the brain and cerebrospinal fluid (4), bromide enters tissue in proportion to the amount of chloride present and after equilibration the ratio of the concentrations of tissue bromide to chloride is the same as in the plasma. ${ }^{2}$ In effect, administered bromide is diluted in body chloride and not in any specific compartment of body water. Thus, the extent of bromide dilution can be used at least as an approximate measure of total body chloride. Measurements of total body chloride, using bromide dilution, in animals and man have been reported by Weir (5) and Dunning, Steele and Berger (6). No data are available, however, on intracellular chloride concentration since previous studies have not included simultaneous measurement of extracellular and intracellular water. The following studies supply data of this type.

\section{METHODS}

Six males and one female without evidence of edema were used in this study. Total body water and extracellular fluid volume were determined with sucrose and antipyrine, ${ }^{3}$ respectively, as described in a preceding paper (7). Intracellular water was calculated as the difference between the antipyrine and sucrose volumes of distribution. Total body solid was calculated as the dif-

1 This study was supported by grants from the Atomic Energy Commission (AEC Contract AT [30-1]-1025) and The Commonwealth Fund to the Department of Physiology and by a grant from the Masonic Foundation for Medical Research to the Study Group for Rheumatic Diseases.

We are indebted to the Fourth (New York University Post-Graduate Medical School) Medical and Surgical Divisions of Bellevue Hospital for the privilege of studying patients on these Services.

2 However, in red blood cells the ratio bromide/chloride may be slightly greater than plasma (2).

8 The antipyrine was supplied in ampoule form through the courtesy of Eli Lilly \& Company, Indianapolis, Indiana. ference between body weight and the weight of the antipyrine volume of distribution, and cellular mass as the difference between body weight and the weight of the sucrose volume of distribution. Bromide was determined by the method of Brodie and Friedman (8) and chloride by the method of Wilson and Ball (9). The bromide method was checked by analysis of plasma solutions of known concentration and gave an average recovery of 99 (range 98 to 102) per cent.

Sodium bromide was administered by a single injection from a calibrated syringe or burette in an amount equivalent to 1.5 to $2.5 \mathrm{gm}$. of bromide. A period of 24 hours was allowed for complete equilibration of bromide before the final blood sample was obtained. Urinary bromide excretion was determined throughout this equilibration period, and utilized to calculate the bromide retained in the body.:

Total body chloride, as determined by bromide dilution was calculated as :

Total body chloride $=$ plasma chloride concentration $\times \frac{\text { retained bromide }}{\text { plasma bromide concentration }}$

In calculating the extracellular chloride $\left(\mathrm{ECF}_{\mathrm{Cl}}\right)$ account must be taken of the plasma volume (PV), Donnan factor (k), plasma water content (w), and extracellular fluid volume (ECF), in accordance with the following equation:

$$
f=\frac{P V+\frac{k}{w}[E C F-P V]}{E C F_{C l} P_{C l}} .
$$

We have not measured PV, $k$ and $w$, but we may with reasonable accuracy take $\mathrm{PV}$ as 4 per cent of the body weight, $k$ as 1.02 and $w$ as 0.92 . Inserting these values and the observed values of ECF yields the individual factors listed under $f$ in Table $I$, which have been used in the calculation of ECFor.

\section{RESULTS AND DISCUSSION}

Table I contains the data from simultaneous measurements of body water compartments and total body chloride in seven subjects. Total chloride ranges from 27.1 to 33.7 and averages 30.1 $\mathrm{mEq} . / \mathrm{kg}$. body weight, figures which may be com-

4 The plasma chloride determination was not corrected for the presence of bromide since the equilibrium bromide concentration was usually less than 2 per cent of total plasma halide. 
INTRACELLULAR CHLORIDR IN MAN

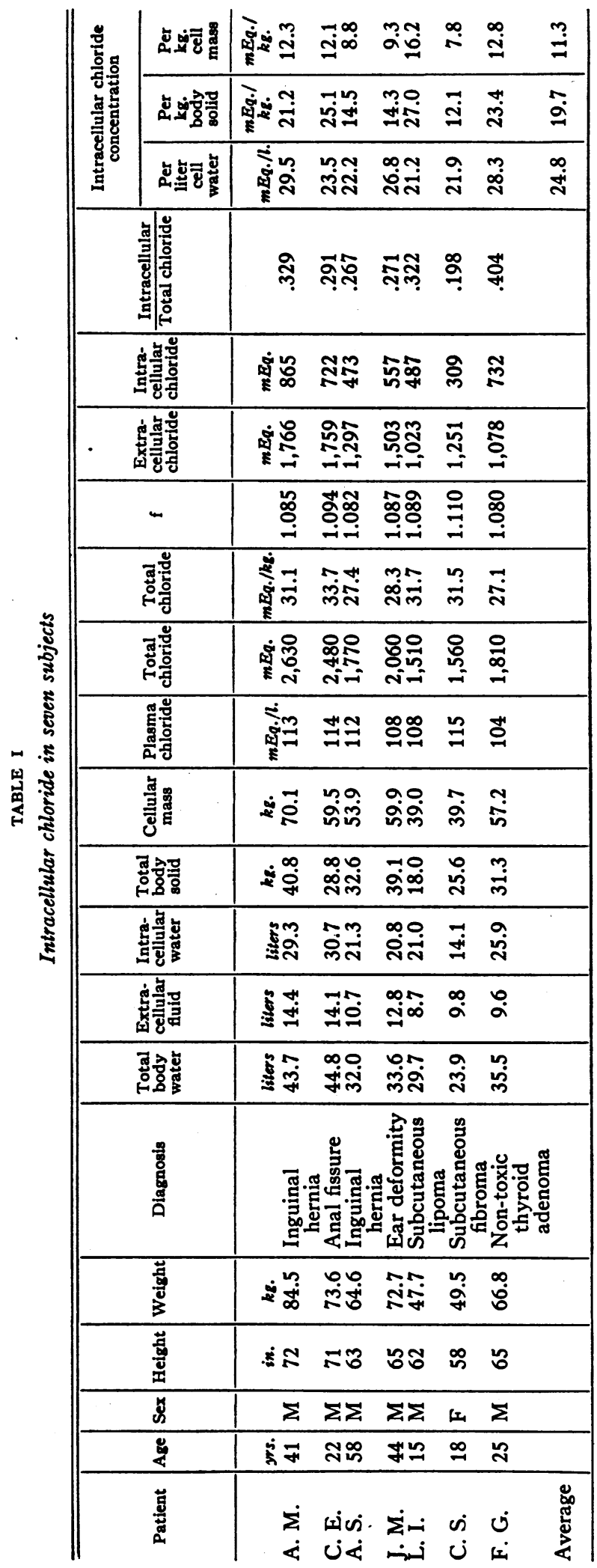


pared with a range of 27.9 to 35.2 and an average of 31.6 in five males without edema reported by Dunning, Steele, and Berger (6). These investigators obtained the slightly lower value of 28.6 $\mathrm{mEq} . / \mathrm{kg}$. in five females. Total body chloride in cats, dogs and rabbits, as measured by bromide dilution, averaged $34.4,33.2$ and $30.2 \mathrm{mEq} . / \mathrm{kg}$., respectively (5), values which are in close agreement with measurements of total body chloride as determined from analyses of homogenized aliquots of animals (10).

Intracellular chloride averaged $24.8 \mathrm{mEq}$./liter of cell water (range 21.2 to 29.5 ). This figure is, of course, a nominal one and does not reveal the true chloride concentration in any one tissue. No data are available for comparison with this value, nor can its accuracy be checked directly.

Intracellular chloride averaged $11.3 \mathrm{mEq} . / \mathrm{kg}$. of cell mass (range 7.8 to 16.2 ) and $19.7 \mathrm{mEq} . / \mathrm{kg}$. of body solid (range 12.1 to 27.0 ).

Dunning, Steele and Berger (6) surmise that about half the body chloride is in the cells, but our data show that the intracellular fraction ranges from 19.8 to 40.4 per cent of the total chloride, with an average ratio of 29.7. However, we concur with their statement that a change in total chloride does not necessarily represent a change in volume of extracellular fluid. The older assumption that chloride is confined to the extracellular fluid must, we think, be abandoned in the light of the present studies, and in view of the excessively large chloride spaces reported by Dunning, Steele and Berger in man (6), by Burch, Threefoot, and Ray (11) in the dog, the high bromide space/inulin space ratio (1.30 to 2.40 ) reported by Berger, Dunning, Steele, Jackenthal and Brodie (12), and the direct analyses of Manery and Hastings (13), Crismon, Crismon, Calabresi and Darrow (14) and Wilde (15). The evidence indicates that intracellular chloride is highly variable in amount, and one may infer from this variability and the viviperfusion experiments of Amberson, Nash, Mulder and Binns (16) that it is also highly labile. Calculation of changes in the extracellular fluid volume from changes in the total body chloride must therefore have an uncertain value.

\section{SUM MARY}

Intracellular chloride has been determined from simultaneous studies of body water distribution (total body water and extracellular fluid) and total body chloride as measured by the bromide dilution method in seven non-edematous subjects.

Total chloride averaged $30.1 \mathrm{mEq} . / \mathrm{kg}$. body weight (range 27.1 to 33.7 ). Intracellular chloride averaged 29.7 per cent of total chloride (range 19.8 to 40.4 ), and $24.8 \mathrm{mEq}$./liter of cell water (range 21.2 to 29.5 ), $11.3 \mathrm{mEq} . / \mathrm{kg}$. of cell mass (range 7.8 to 16.2 ), and $19.7 \mathrm{mEq} . / \mathrm{kg}$. of body solid (range 12.1 to 27.0 ).

In view of the large fraction of total body chloride which is contained in the cells, changes in total body chloride cannot be accepted as necessarily reflecting changes in extracellular fluid volume.

\section{REFERENCES}

1. Weir, E. G., The relationship between the halides of body fluids and of the tissues. Doctoral Thesis, University of Chicago, 1936.

2. Weir, E. G., and Hastings, A. B., The distribution of bromide and chloride in tissues and body fluids. J. Biol. Chem., 1939, 129, 547.

3. Wallace, G. B., and Brodie, B. B., The distribution of administered bromide in comparison with chloride and the relation to body fluids. J. Pharm. \& Exper. Therap., 1939, 65, 214.

4. Wallace, G. B., and Brodie, B. B., The distribution of iodide, thiocyanate, bromide and chloride in the central nervous system and spinal fluid. J. Pharm. \& Exper. Therap., 1939, 65, 220.

5. Weir, E. G., Determination of the total chloride content of animals following administration of sodium bromide. Am. J. Physiol., 1939, 127, 338.

6. Dunning, M. F., Steele, J. M., and Berger, E. Y., The measurement of total body chloride. Proc. Soc. Exper. Biol. \& Med., 1951, 77, 854.

7. Deane, N., and Smith, H. W., The distribution of sodium and potassium in man. J. Clin. Invest., 1952, 31, 197.

8. Brodie, B. B., and Friedman, M. M., The determination of bromide in tissues and biological fluids. $\mathrm{J}$. Biol. Chem., 1938, 124, 511.

9. Wilson, D. W., and Ball, E. G., A study of the estimation of chloride in blood and serum. J. Biol. Chem., 1928, 79, 221.

10. Harrison, H. E., Darrow, D. C., and Yannet, H., The total electrolyte content of animals and its probable relation to the distribution of body water. J. Biol. Chem., 1936, 113, 515.

11. Burch, G. E., Threefoot, S. A., and Ray, C. T., Rates of turnover and biologic decay of chloride and chloride space in the dog determined with the longlife isotope, $\mathrm{Cl}^{*}$. J. Lab. \& Clin. Med., 1950, 35, 331.

12. Berger, E. Y., Dunning, M. F., Steele, J. M., Jacken- 
thal, R., and Brodie, B. B., Estimation of intracellular water in man. Am. J. Physiol., 1950, 162, 318.

13. Manery, J. F., and Hastings, A. B., The distribution of electrolytes in mammalian tissues. J. Biol. Chem., 1939, 127, 657.

14. Crismon, J. M., Crismon, C. S., Calabresi, M., and Darrow, D. C., Electrolyte redistribution in cat heart and skeletal muscle in potassium poisoning. Am. J. Physiol., 1943, 139, 667.

15. Wilde, W. S., The chloride equilibrium in muscle. Am. J. Physiol., 1945, 143, 666.

16. Amberson, W. R., Nash, T. P., Mulder, A. G., and Binns, D., The relationship between tissue chloride and plasma chloride. Am. J. Physiol., 1938, 122, 224. 